\title{
Bernard Arief Sidharta: Dari Pengembanan Hukum Teoretis ke Pembentukan Ilmu Hukum Nasional Indonesia
}

\author{
Shidarta \\ Jurusan Hukum Bisnis Universitas Bina Nusantara \\ shidarta@binus.edu
}

\begin{abstract}
Bernard Arief Sidharta has made a significant contribution to Indonesia in the development of the legal discipline. He took the lead in introducing the state-of-the art legal discipline, particularly within his translation of legal textbooks in Dutch. He is also a figure of Indonesian legal theorists and legal philosophers offering interesting ideas, which in this paper, his commentaries will be confined to three areas: the foundation for the theoretical legal functioning, legal reasoning, and the Indonesian national legal science. Arief conducted a very comprehensive study of the first two areas, which later became the basis for national legal science. The national legal science should be based on the legal idea of Pancasila, a view that was heavily influenced by the thoughts of Soediman Kartohadiprodjo and then Mochtar Kusuma-Atmadja. This legal idea is as an immanent value which becomes the base value for describing the source of Indonesia's material law, and as a transcendent value that directs where the Indonesian national legal system will proceed. Regrettably, Arief has not finished talking about the elaboration of the legal idea of Pancasila so that it can substantially and practically give a distinctive color to the national legal science that he aspires to.
\end{abstract}

Keywords: Arief Sidharta; legal discipline; legal reasoning; Pancasila; Indonesian national legal science. 


\section{Abstrak}

Bernard Arief Sidharta memiliki kontribusi penting bagi Indonesia dalam pengembangan disiplin hukum. Ia adalah orang pertama yang memperkenalkan bangunan disiplin hukum dalam wacana kekinian, khususnya melalui karya terjemahannya atas buku-buku teks hukum berbahasa Belanda. Ia juga adalah sosok teoretisi hukum dan filsuf hukum Indonesia yang menawarkan pemikiran menarik, yang di dalam tulisan ini, akan dibatasi ulasannya pada tiga area. Bidang-bidang itu adalah tentang landasan pengembanan hukum teoretis, penalaran hukum, dan ilmu hukum nasional Indonesia. Arief melakukan kajian yang sangat komprehensif terhadap dua area yang pertama, untuk kemudian menjadikannya sebagai dasar-dasar bagi ilmu hukum nasional Indonesia. Ilmu hukum nasional tersebut harus berintikan cita hukum Pancasila, suatu pandangan yang banyak dipengaruhi pertama-tama oleh pemikiran Soediman Kartohadiprodjo dan kemudian oleh Mochtar KusumaAtmadja. Cita hukum ini berfungsi baik sebagai nilai imanen yang menjadi nilai-dasar untuk mendeskripsikan sumber hukum material Indonesia, maupun sebagai nilai transenden yang mengarahkan ke mana tata hukum nasional Indonesia itu akan berproses. Sangat disayangkan, Arief belum tuntas berbicara tentang penjabaran cita hukum Pancasila itu agar secara substansial dan implementatif dapat memberi warna yang khas bagi ilmu hukum nasional Indonesia yang dicita-citakannya.

Kata kunci: Arief Sidharta; disiplin hukum; penalaran hukum; Pancasila; ilmu hukum nasional Indonesia.

\section{A. Pendahuluan}

Artikel ini menampilkan sosok dan pemikiran hukum dari Bernard Arief Sidharta. Dalam studi hukum di Indonesia, nama tokoh ini dapat dipastikan dikenali oleh setiap peminat dan penstudi filsafat hukum dan/atau teori hukum, terutama lewat karya-karya yang dihasilkannya. Arief, demikian tulisan ini selanjutnya menyebut tokoh ini, memang dikenali menghasilkan karya-karya tulis yang spektakuler karena mampu mengisi kelangkaan bacaan di bidang itu. Naluri akademisnya sangat tajam untuk memilih secara selektif sumber-sumber tulisan yang layak diterjemahkan atau ditulisnya. 
Tidak heran apabila buku-bukunya dibaca secara luas, khususnya di kalangan peserta didik di tingkat pascasarjana (ilmu) hukum.

Dalam artikel ini, pemikiran hukum dari Arief akan didiskusikan melalui tiga area kajian yang menjadi fokus perhatiannya. Area pertama berkenaan dengan landasan pengembanan hukum teoretis, sebuah ranah yang luas yang memberi tempat bermukim bagi tiga cabang disiplin hukum: ilmu hukum dogmatis, teori (ilmu) hukum, dan filsafat hukum. Fokus perhatian berikutnya merupakan area yang lebih spesifik dari pengembanan hukum teoretis itu, yakni penalaran hukum. Ranah yang semula kurang mendapat perhatian ini, seperti tergugah melalui beberapa buku dan artikel buah tangan Arief. Selanjutnya, akan dijelajahi area ketiga yang menjadi obsesi ilmiah beliau, yaitu pengembangan (harap bedakan dengan "pengembanan") ilmu hukum nasional Indonesia. Setelah deskripsi riwayat hidup dan karya-karyanya, sistematika tulisan ini akan setia mengikuti tiga area fokus perhatian Arief tersebut, sebelum kemudian diakhiri dengan catatan penutup.

\section{B. Riwayat Hidup dan Karya}

Bernard Arief Sidharta dikenal luas sebagai salah satu dari sedikit filsuf hukum Indonesia yang produktif, selektif, dan serius dalam karya-karyanya. Sebagian dari publikasinya itu memang merupakan hasil translasi atau saduran dari tulisan berbahasa Belanda atau Inggris, tetapi hal ini justru menunjukkan posisi keilmiahan seorang Arief di mata para pengemban hukum (istilah temuannya yang diterjemahkannya dari kata 'rechtsbeoefenaren') di Tanah Air. Banyak pihak mengira, Arief menguasai dengan fasih bahasa Belanda karena berasal dari latar belakang keluarga menengah-atas berpendidikan Belanda. Padahal, latar belakang keluarganya sangat kontras dengan dugaan tersebut. Ayahnya bekerja sebagai karyawan biasa dan juga mencoba berwirausaha kecil-kecilan.

Arief lahir di Garut, 8 Oktober 1939 dari keluarga sangat sederhana. Ia anak ketiga dari sepuluh bersaudara dari pasangan Tjie Tiam Tjeng (ayah) dan Kho Hie Nio (ibu), yang semula bermukim 
di Banjarnegara (Jawa Tengah). Setelah menikah, mereka memilih berdomisili di Garut, di sebuah rumah sewaan di Jalan Talaga Bodas. Nama kecil Bernard Arief Sidharta adalah Tjie Tek Tjoan. Nama Arief Sidharta sebenarnya baru resmi digunakannya pada 1967.

Jika ditelusuri ke belakang, orangtua Arief berasal dari etnis Hokkien, salah satu sub-etnis Tionghoa yang cukup dominan di Indonesia. Namun, seperti kebanyakan keluarga Tionghoa di Indonesia yang lahir dan menetap di daerah rural atau kota-kota kecil, mereka praktis tidak lagi menguasai bahasa leluhurnya dan lebih memilih untuk menggunakan bahasa setempat sebagai bahasa sehari-hari. Arief sendiri menempuh pendidikan dasar dan menengah di kota kelahirannya. ${ }^{1}$

Oleh karena masa kecil dan remajanya dihabiskan di lingkungan yang kental dengan budaya Sunda, maka Arief sendiri lebih mengidentifikasikan dirinya sebagai urang asli Garut (asgar). Nama Bernard (Bernardus) diperoleh setelah Arief menjadi Katolik dan kuliah di Universitas Katolik Parahyangan. Di dalam keluarganya, dari sembilan saudara kandungnya, ada dua orang lagi yang memeluk agama Katolik. Lima memeluk agama Kristen dan dua yang lain beragama Islam. Dalam beberapa pembicaraan santai dengan Arief, beliau menunjukkan rasa bangga dengan keanekaragaman keyakinan di dalam keluarga besarnya. Ia juga senang dapat mengajar di berbagai perguruan tinggi dengan bermacam latar belakang, salah satu di antaranya di Universitas Islam Indonesia (UII), Yogyakarta.

Pada 1957 Arief pergi ke Bandung untuk meneruskan kuliah di Universitas Padjadjaran. Sayangnya, ia terlambat mendaftar, sehingga ia beralih kuliah di Fakultas Ekonomi Universitas Katolik Parahyangan. Setahun kemudian, universitas ini membuka fakultas yang baru, yaitu Fakultas Hukum. Arief kemudian memutuskan pindah studi karena lebih menyenangi belajar hukum daripada

1 Informasi tentang latar belakang keluarga dan masa kecil Bernard Arief Sidharta dicuplik dari tulisan Haryo Damardono, "Penziarahan Arief Sidharta Demi Ilmu Hukum Indonesia,” dalam Bernard Arief Sidharta Penziarah Hukum Indonesia, ed. Shidarta, Tristam P. Moeliono, dan Tanius Sebastian (Jakarta: HuMa \& Epistema Institute, 2016), hlm. 1-23. 
ekonomi. Sambil kuliah ia bekerja sebagai staf di bagian administrasi Universitas Katolik Parahyangan, yang saat itu berlokasi di jalan Merdeka, Bandung.

Kampus inilah yang memberi kesempatan bagi Arief untuk bertemu dengan banyak tokoh penting yang memengaruhi pemikirannya. Beberapa tahun kemudian ia menjadi dosen dan pimpinan fakultas, serta sempat menjadi anggota Dewan Perwakilan Daerah (DPRD) Provinsi Jawa Barat selama dua periode (1971-1981). ${ }^{2}$ Namanya masih tercatat sebagai pendiri kantor hukum (lawfirm) Sidharta, Pohan, dan Prastowo di Bandung; walaupun ia tidak pernah aktif mengelola kantor tersebut.

Tokoh pertama yang sangat dikagumi Arief adalah Soediman Kartohadiprodjo, guru besar yang menjadi Dekan Fakultas Hukum saat ia kuliah. Dari Soediman, Arief mendapat banyak pembelajaran tentang filsafat Pancasila. ${ }^{3}$ Dia juga sempat menjadi asisten Bushar Muhammad, yang membuat Arief cukup intens mempelajari asas-asas hukum adat. Beliau juga memiliki kedekatan dengan Mochtar Kusuma-Atmadja ${ }^{4}$ dan Sunaryati Hartono, dua orang yang

2 Menurut Ateng Syafrudin (guru besar hukum administrasi negara di Fakultas Hukum Universitas Katolik Parahyangan dan mantan Asisten Bidang Pemerintahan Provinsi Jawa Barat), ketika menjadi anggota DPRD Jawa Barat, Arief adalah penggagas dari program Masyarakat Jawa Barat Gemar Belajar (Learning Society) . Program ini kemudian menjadi embrio dari program Wajib Belajar. Lihat: Sri Rahayu Oktoberina dan Niken Savitri, eds. Butir-Butir Pemikiran dalam Hukum: Memperingati 70 Tahun Prof. Dr. B. Arief Sidharta, S.H. (Bandung: Refika Aditama, 2008), hlm. 289.

3 Arief Sidharta menjadi salah satu editor bersama Achmad Suhardi Kartohadiprodjo, Harjono Kartohadiprodjo, Bambang Utoyo Kartohadiprodjo, dan Budiono Kartohadiprodjo dalam buku Prof. Mr. Soediman Kartohadiprodjo tentang Pancasila sebagai Pandangan Hidup Bangsa Indonesia (Jakarta: Gatra Pustaka, 2010). Dalam buku ini dimuat pidato dies Arief Sidharta berjudul "Revisitasi Pemikiran Prof. Soediman Kartohadiprodjo tentang Pancasila Berkaitan dengan Pengembangan Tatanan Hukum Nasional Indonesia,” hlm. 359-395.

4 Penulisan nama Kusuma-Atmadja ini adalah atas keinginan Mochtar, sekalipun dalam berbagai buku ia menuliskan nama belakangnya dengan Kusumaatmadja. Mengenai hal ini baca: Shidarta, ed. Mochtar KusumaAtmadja dan Teori Hukum Pembangunan: Eksistensi dan Implikasi (Jakarta: Epistema Institute-HuMa, 2012), hlm. 1. 
memperkaya pemikirannya tentang pembangunan sistem hukum Indonesia.

Mochtar Kusuma-Atmadja dan Sunaryati Hartono (juga Komar Kantaatmadja) adalah tim promotor untuk pendidikan doktor Arief di Universitas Padjadjaran (lulus 1996). Disertasi yang ditulis oleh Arief merupakan salah satu karya monumental yang mengajak para penstudi hukum, khususnya di tingkat pascasarjana, untuk menemukan pijakan yang kokoh dari keilmuan ilmu hukum itu. Disertasi yang diterbitkannya menjadi buku berjudul Refleksi tentang Struktur Ilmu Hukum: Sebuah Penelitian tentang Fundasi Kefilsafatan dan Sifat Keilmuan Hukum sebagai Landasan Pengembangan Ilmu Hukum Nasional Indonesia (1999) sekaligus merupakan jawaban Arief atas pertanyaan banyak orang selama ini tentang ke mana ilmu hukum di Indonesia harus diarahkan.

Kendati sejumlah buku atau artikel yang telah dipublikasikannya adalah karya terjemahan, khususnya dari sumber berbahasa Belanda, terbukti hanya beliau yang mampu mengalihbahasakan karyakarya itu dengan sangat baik. Arief pernah menceritakan bahwa ketertarikannya untuk menerjemahkan karya-karya penulis asing itu sebenarnya lebih sebagai pekerjaan sambilan. Dengan menerjemahkan, ia mengaku dapat lebih fokus memahami dengan sebenarbenarnya apa yang dimaksud oleh penulisnya.

Arief tergolong sangat hati-hati dalam melakukan translasi agar sedapat mungkin ia tidak sampai mengubah struktur kalimat pengarang asli. Itulah sebabnya, cukup banyak terjemahannya yang tidak langsung dipublikasikannya karena butuh pengendapan. Ada sejumlah karya yang bahkan tetap dibiarkannya dalam bentuk manuskrip yang beredar secara internal di lingkungan dosen dan mahasiswa di tempatnya mengajar atau diedarkan dengan mengatasnamakan Laboratorium Hukum atau Pusat Kajian Humaniora Fakultas Hukum Universitas Katolik Parahyangan. Memang ada beberapa yang kemudian diterbitkannya di jurnal Pro Justitia. Dalam curriculum vitae-nya yang disampaikan saat ia menjadi orator

5 Saat ini Jurnal Pro Justitia telah berhenti terbit dan sebagai gantinya telah diterbitkan jurnal baru dengan nama Veritas et Justitia. 
dies natalis ke-51 Fakultas Hukum Universitas Katolik Parahyangan, Arief mencantumkan 33 artikel/paper yang sudah dipublikasikan, 6 buku, 13 tulisan di media cetak, 18 karya terjemahan, dan puluhan makalah yang disajikan dalam berbagai pertemuan ilmiah.

Ia juga rajin menyumbangkan pemikiran untuk menghormati rekan-rekannya dalam kumpulan karangan (antologi), antara lain didedikasikan untuk: Komar Kantaatmadja (ia menulis esai berjudul “Tinjauan Yuridis tentang Judicial Review," 1998); Mochtar KusumaAtmadja ("Pendidikan Tinggi Hukum di Indonesia," 1999); Satjipto Rahardjo ("Praktisi Hukum dan Perkembangan Hukum," 2000); Sunaryati Hartono ("Sebuah Gagasan tentang Paradigma Ilmu Hukum Indonesia,” 2011); dan Valerine J.L. Kriekhoof ("Penemuan Hukum dalam Kajian Filsafat Hukum,” 2014).

Satu kebiasaan Arief yang pasti diingat oleh rekan-rekan sesama dosen dan mahasiswa yang kerap berinteraksi dengannya adalah kemurahan hatinya untuk berbagi pengetahuan. Ia misalnya tidak segan untuk memberikan makalah seminar dan draf terjemahan yang baru saja dikerjakannya. Tulisan-tulisannya yang masih hangat (fresh from the oven) itu kemudian beredar dari tangan ke tangan. Sebagian ada yang sempat diserahkannya ke Jurnal Pro Justitia untuk diterbitkan atau dikemas menjadi buku yang diperbanyaknya sendiri. Contoh dari sebagian kecil draf hasil terjemahan/saduran itu adalah tulisan-tulisan dari H.D.C. Roscam Abbing ("Pertanggunggugatan Perdata Rumah Sakit”), Ayn Rand ("Filsafat, Siapa yang Membutuhkannya?”), J.J. van Eukema Hommes ("Hubungan Aspek Hukum dan Aspek Kehidupan Lain”), A. Soeteman ("Kebenaran Menurut Ilmu Hukum"), Irving Copi ("Logika dan Hukum"), R.J. Jue ("Analisis Kaidah Hukum"), M.A, Loth ("Menilai dan Memutus dalam Pertentangan Pendapat: Rasionalitas Putusan Hakim”), dan C.W. Maris ("Aliran Filsafat Hukum Abad 20").

Dari paparan karya-karya di atas, dapat ditelusuri spektrum minat akademis seorang Bernard Arief Sidharta. Pertama, ia menyenangi filsafat ilmu. Dalam konteks ini ia sangat serius mendalami karya C.A. van Peursen. Dari sini kemudian ia masuk ke filsafat ilmu hukum dan teori [ilmu] hukum, sebagaimana terlihat dari 
pembacaannya terhadap pemikiran H. Ph. Vissert't Hooft, D.H.M. Meuwissen, J.J.H. Bruggink, Carel Smith, dan Arend Soeteman. Lalu, ada bidang logika dan penalaran hukum, seperti telaahannya atas karya-karya Irving Copi, Kelsen, M.Henket, dan J.A. Pontier. Apabila dicermati artikel-artikel dan makalah-makalah yang ditulisnya, Arief juga menyukai diskursus tentang pendidikan tinggi hukum, ${ }^{6}$ filsafat [hukum] Pancasila, ${ }^{7}$ dan ilmu hukum Indonesia.

Dalam tulisan singkat ini tentu tidak mungkin dibahas semua area peminatan beliau itu. Tulisan ini hanya akan menyoroti tiga zona peminatannya yang kiranya cukup kontributif bagi pengembangan ilmu hukum di Tanah Air. Di bawah ini dapat ditemukan sedikitnya 18 buah pena Arief Sidharta yang bersinggungan erat dengan tiga bidang yang akan menjadi objek bahasan tulisan ini, yakni landasan pengembanan hukum teoretis, penalaran hukum, dan pembentukan ilmu hukum Indonesia.

1. Buku: Hukum dan Logika, terjemahan karangan Hans Kelsen, Essays in Legal and Moral Philosophy (Bandung; Alumni, 1982).

2. Buku: Filsafat Hukum, Mazhab dan Refleksinya (Badung; Remaja Rosda Karya, 1989). Buku ini disunting oleh Arief Sidharta bersama dengan Lili Rasjidi.

3. Artikel: "Penyelesaian Kasus" (Jurnal Pro Justitia No. 1, 1994) terjemahan karangan Gr. van der Borght dan J.D.C. Winkelman.

4. Artikel: "Pengembanan Hukum" (Jurnal Pro Justitia No. 1, 1994), "Teori Hukum" (Jurnal Pro Justitia No. 2, 1994), "Filsafat Hukum" (Jurnal Pro Justitia No. 3, 1994), dan "Ilmu Hukum" (Jurnal Pro Justitia No. 4, 1994). Semua tulisan tersebut adalah terjemahan dari karangan D.H.M. Meuwissen, Een Beeld van Recht (artikel Jurnal Hukum Ars Aequi, edisi khusus 1979), dan tiga tulisan Meuwissen yang diambil dari Bab XV, XVI, dan XVIII di dalam buku berjudul

6 Arief pernah menulis opini di Harian Kompas, 18/10/1979, berjudul "Studi dan Profesi Hukum Hanya untuk Orang Bodoh?” Beliau juga pernah menjadi anggota Konsorsium Ilmu Hukum ketika lembaga ini dipimpin oleh Mochtar Kusuma-Atmadja.

7 Lihat antara lain orasi dies ke-51 Fakultas Hukum Universitas Katolik Parahyangan yang disampaikan oleh Arief Sidharta di Bandung, tanggal $17 / 10 / 2009$. 
Van Apeldoorn's Inleiding tot de Studie van het Nederlandse Recht, edisi tahun 1985. Tiga belas tahun kemudian sejak diterbitkan di Jurnal Pro Justitia dan telah dibaca cukup banyak orang, semua karya terjemahan ini disatukannya kembali ke dalam satu buku berjudul Meuwissen tentang Pengembanan Hukum, Ilmu Hukum, Teori Hukum, dan Filsafat Hukum (Bandung: Refika Aditama, 2007). Khususuntuk tulisan mengenai "pengembanan hukum" karya Meuwissen, Arief memandang perlu untuk mengelaborasinya menjadi satu tulisan tersendiri dengan struktur tulisan yang berbeda dengan karya awal D.H.M. Meuwissen. Tulisan ini kemudian ditampilkan dalam buku: Bernard Arief Sidharta: Penziarah Hukum Indonesia, suntingan Shidarta, Tristam P. Moeliono, dan Tanius Sebastian (Jakarta: HuMa-Epistema Institute, 2016), hlm. 131-156.

5. Artikel: "Filsafat dan Ideologi Pancasila(Beberapa Pokok Pikiran)" (Jurnal Pro Justitia No. 1, 1994).

6. Buku: Refleksi tentang Hukum: Pengertian-Pengertian Dasar dalam Teori Hukum, terjemahan karanganJ.J.H. Bruggink, Rechtsreflecties: Grondbegrippen uit de Rechtstheorie (Bandung: Citra Aditya Bakti, 1995). Buku ini ditujukannya untuk pembelajaran teori hukum yang diajarkan di program pascasarjana.

7. Buku: Pengantar Ilmu Hukum: Suatu Pengenalan Pertama Ruang Lingkup Berlakunya Ilmu Hukum, Buku I (Bandung; Alumni, 1999). Buku ini ditulis bersama dengan Mochtar Kusuma-Atmadja.

8. Manuskrip: Apakah Teori Hukum Itu?, terjemahan karangan Gijssels-Hoecke, Wat is Rechtstheorie? (Bandung: Laboratorium Hukum Fakultas Hukum Universitas Katolik Parahyangan, 2000).

9. Artikel: "Disiplin Hukum: Tentang Hubungan antara Ilmu Hukum, Teori Hukum, dan Filsafat Hukum (State of the Arts)" (Jurnal Pro Justitia No. 3, 2002). Di kemudian hari, dua murid beliau, yaitu Anthon F. Susanto dan Shidarta, menerbitkan ulang artikel ini sebagai bab pertama dari karangan mereka bertiga berjudul: Pengembanan Hukum Teoretis: Refleksi atas Konstelasi Disiplin Hukum (Bandung: Logoz, 2014).

10. Buku: Struktur Ilmu Hukum, terjemahan karangan Paul Scholten, 
De Structuur der Rechtswetenshap (Bandung: Alumni, 2003).

11. Manuskrip: Teori Argumentasi dan Hukum, terjemahan karangan M. Henket (Bandung: Laboratorium Hukum Fakultas Hukum Universitas Katolik Parahyangan, 2003).

12. Manuskrip: Filsafat Ilmu, terjemahan karangan C.A. van Peursen, Filosofie van de Wetenschappen (Bandung: Pusat Kajian Humaniora Universitas Katolik Parahyangan, 2005).

13. Buku: Penemuan Hukum, terjemahan karangan J.A. Pontier, Rechtsvinding (Bandung: Jendela Mas Pustaka, 2008).

14. Buku: Pengantar Logika: Sebuah Langkah Pertama Pengenalan Medan Telaah (Bandung: Refika Aditama, 2008). Buku ini diterbitkan dalam rangka ulang tahun ke-70 Bernard Arief Sidharta.

15. Manuskrip: Filsafat Ilmu Hukum, terjemahan karangan H. Ph. Vissert't Hooft, Filosofie van den Rechtswetenschap (Bandung: Laboratorium Hukum Fakultas Hukum Universitas Katolik Parahyangan, 2009).

16. Manuskrip: Karakter Normatif Ilmu Hukum: Hukum Sebagai Penilaian, terjemahan karangan Carel Smith, Het Normatieve Karakter van de Rechtswetenschap: Recht Als Oordeel (Bandung: Fakultas Hukum Universitas Katolik Parahyangan, 2010).

17. Manuskrip: Ilmu Hukum yang Ilmiah: Komentar terhadap Prasaran Carel Smith tentang Karakter Normatif Ilmu Hukum, terjemahan karangan Arend Soeteman, Wetenschappelijke rechtsgeleerdheid Commentaar op het Preadvies van Carel Smith (Bandung: Fakultas Hukum Universitas Katolik Parahyangan, 2010).

18. Buku: Imu Hukum Indonesia: Upaya Pengembangan Ilmu Hukum Sistematik yang Responsif terhadap Perubahan Masyarakat (Yogyakarta: Genta Publishing, 2013). Buku ini kemudian diterbitkan ulang oleh Unpar Press tahun 2016 (edisi revisi).

Buku berjudul Ilmu Hukum Indonesia pada urutan ke-18 adalah karyanya yang terakhir sebelum beliau berpulang pada 24 November 2015 di kota Bandung dalam usia 76 tahun. Buku ini merupakan "janji” yang sejak lama dipersiapkannya karena terhubung langsung dengan karya disertasinya. Naskah buku ini sebenarnya sudah cukup lama dipersiapkan, bahkan sempat diterbitkan dalam prosiding Kongres 
Ilmu Hukum yang diselenggarakan di Semarang atas kerja sama Asosiasi Sosiologi Hukum Indonesia (ASHI) dan Bagian Hukum dan Masyarakat Fakultas Hukum Universitas Diponegoro (Oktober 2012).

Kecintaan beliau kepada negeri kelahiran dan tumpah darahnya dituangkan tidak hanya dalam wujud tulisan. Misalnya, bersama Soetandyo Wignjosoebroto dan Shidarta, ia aktif menjadi pengajar tetap dalam rangkaian seri perkuliahan dan pelatihan yang dikelola oleh Epistema Institute. Kegiatan ini sempat berjalan beberapa angkatan, yang hampir seluruh peserta adalah dosen-dosen muda dan para aktivis lembaga swadaya masyarakat. Beliau juga adalah salah satu pendiri dan ketua pertama Asosiasi Filsafat Hukum Indonesia (AFHI).

Di mana perlu, ia juga tidak segan tampil menyuarakan pandangannya membela gerakan/pemikiran demokrasi, anti-korupsi, dan anti-hukuman mati. Saat-saat menjelang kejatuhan Orde Baru, di tengah kondisi kerawanan Jakarta, ia ikut menemani mahasiswa dari kampusnya di Bandung berangkat ke ibukota negara guna menunjukkan simpati pada gerakan reformasi. Beberapa bulan sebelum ia wafat, Arief bahkan hadir sebagai ahli di persidangan praperadilan Budi Gunawan yang mempermasalahkan penetapan mantan Calon Kapolri itu sebagai tersangka oleh Komisi Pemberantasan Korupsi. Hakim Sarpin yang memimpin persidangan itu mencuplik keterangan Arief di persidangan sebagai dasar penalarannya untuk sampai pada diktum mengabulkan permohonan Budi Gunawan, sehingga penetapan Budi Gunawan sebagai tersangka dibatalkan. Ketidaktepatan hakim menangkap esensi keterangan Arief di muka persidangan sungguh-sungguh mengecewakannya. Arief mengungkapkan kekhawatirannya bahwa akibat kekeliruan hakim menangkap maksud keterangannya itu, bakal memutarbalikkan persepsi publik, khususnya pada anak-anak didiknya, bahwa Arief kini telah berubah, dan ia termasuk barisan yang ingin memperlemah posisi Komisi Pemberantasan Korupsi (KPK). Suatu sikap yang ditolaknya dengan tegas. 


\section{Landasan Pengembanan Hukum Teoretis}

Seperti dinyatakan di awal tulisan ini, Arief adalah orang pertama yang memperkenalkan istilah "pengembanan hukum" (dari kata kerja dasar "emban" yang secara leksikal berarti melaksanakan). ${ }^{8}$ Susur galur kata ini memang dari bahasa Belanda: rechtsbeoefening. Sebagai penerjemah, ia berpikir keras untuk mencari padanan kata yang tepat untuk istilah tersebut, sampai akhirnya memutuskan untuk menggunakan kata "pengembanan hukum." Menurutnya, terminologi pengembanan di sini digunakan dalam arti memikul atau menyandang tugas dan kewajiban untuk melaksanakan, menjalankan, mengurus, memelihara, mengolah, dan mengembangkan suatu jenis kegiatan tertentu, dan secara moral bertanggung jawab untuk itu. ${ }^{9}$

Kecintaan Arief pada pengembanan hukum teoretis (theoretische rechtsbeofening) mengantarkannya menjadi seorang ahli hukum yang mumpuni. Bagi siapa saja yang mengenal beliau dari dekat, akan sampai pada kesimpulan bahwa Arief seorang yang sangat menguasai fondasi keilmuan hukum itu sebagaimana terlacak dari hasil penelitian disertasinya. Misalnya saja, beliau adalah orang pertama yang menyajikan bangunan disiplin hukum dalam wacana kekinian (state of the arts) kepada komunitas hukum di Indonesia. Bangunan ini didapatinya setelah mempelajari berbagai literatur terbaru yang umumnya diambil dari sumber penulis-penulis Belanda, khususnya D.H.M. Meuwissen. ${ }^{10}$ Konstelasi disiplin hukum ini sangat membantu

8 Departemen Pendidikan Nasional Republik Indonesia, Kamus Besar Bahasa Indonesia (Jakarta: Balai Pustaka, 2005), hlm. 296.

9 Lihat catatan kaki nomor 180 pada Shidarta, Moeliono, dan Sebastian (ed.), Bernard Arief Sidharta Penziarah Hukum, hlm. 131.

10 Meuwissen adalah salah seorang penulis di dalam buku: P. van Dijk et al., Van Apeldoorn's Inleiding tot de Studie van het Nederlandse Recht, cetakan ke-18 (Zwolle: W.E.J. Tjeenk Willink, 1985). Sekalipun judul buku ini mengacu pada penghormatan atas karya Van Apeldoorn, tidak lagi ditemukan satupun tulisan Apeldoorn yang tersisa di dalam buku tersebut. Dalam karya aslinya, Apeldoorn membagi pohon keilmuan hukum ke dalam tiga kelompok, yaitu kesenian hukum, ilmu pengetahuan hukum, dan filsafat hukum. Kesenian hukum mencakup perundang-undangan, peradilan, dan ajaran hukum; sedangkan ilmu pengetahuan hukum terdiri dari sosiologi hukum, sejarah hukum, dan perbandingan hukum. Baru kemudian terakhir berupa filsafat hukum, yang mempertanyakan tentang tiga hal: 
pemahaman tentang fondasi kefilsafatan dari ilmu hukum dalam arti luas, yakni disiplin hukum.

Sebelum beliau, konstelasi kedisiplinan hukum dipahami antara lain melalui tulisan Purnadi Purbacaraka dan Soerjono Soekanto (melalui buku Perihal Kaedah Hukum, 1978) ${ }^{11}$ dengan membedakan disiplin hukum itu menjadi ilmu hukum, politik hukum, dan filsafat hukum. Ilmu hukum dibedakan lagi menjadi ilmu tentang kaidah (Normwissenschaft atau Sollenwissenschaft), ilmu tentang pengertian (Begriffenwissenschaft; Kamphuysen), dan ilmu tentang kenyataan (Tatsachenwissenschaft). Uniknya, tatkala Purnadi dan Soerjono menjelaskan tentang cabang-cabang disiplin hukum ini, mereka tidak mengutipnya dari satu sumber, melainkan mengambil dari tulisan P. Vinke dan kemudian dari V. Aubert. ${ }^{12}$ Lebih unik lagi, kedua buku tersebut ternyata berkaitan dengan sosiologi hukum. Sayangnya lagi, Purnadi dan Soerjono tidak cukup konsisten dalam membangun landasan berpikir, sebagaimana terlihat dari kebingungan mereka ketika menerjemahkan terminologi legal theory yang kadang diartikan sebagai disiplin hukum, dan di lain waktu sebagai ilmu hukum (kendali dalam arti luas). Dalam buku mereka berdua berjudul Sendi-Sendi Ilmu Hukum dan Tata Hukum (1979), malahan pembagian disiplin hukum ini tidak disinggung sama sekali. Pada kesempatan lain, ada pula yang mengidentikkan teori hukum itu sebagai satu kesatuan dengan filsafat hukum. ${ }^{13}$

(1) adakah pengertian hukum yang berlaku umum?, (2) apakah dasar kekuatan mengikat dari hukum?, dan (3) adakah sesuatu hukum kodrat? Jadi, pandangan Meuwissen juga telah keluar dari pembagian lama yang disodorkan oleh Apeldoorn. Lihat L.J. van Apeldoorn, Pengantar Ilmu Hukum, terj. Oetarid Sadino (Jakarta: Pradnya Paramita, 1954), hlm. 387489.

11 Purnadi Purbacaraka dan Soerjono Soekanto, Perihal Kaedah Hukum (Jakarta: Alumni, 1978), hlm. 9-11.

12 P. Vinke, Wat is en Waaroom Rechtssociologie? (Kluwer: Deventer, 1970) dan V. Aubert, Sociology of Law (Middlesex: Penguin Books, 1975).

13 Lihat Purnadi Purbacaraka dan M. Chidir Ali, Disiplin Hukum (Bandung: Alumni, 1986), hlm. vii-viii. Dalam kata pengantar buku ini ditegaskan bahwa sebagian isinya mengambil tulisan Wolfgang Friedmann berjudul Legal Theory yang diterjemahkan mereka menjadi disiplin hukum. Jadi, kata "legal theory" terkadang dimaknai sebagai disiplin hukum mencakup 
"Kebingungan" atas bangunan disiplin hukum ini bukanlah persoalan kecil karena hal ini memperlihatkan ketidakpedulian penstudi hukum terhadap akar keilmuan yang mereka tekuni. Apalagi jika "kebingungan" ini sampai mampir di buku-buku teks dan kuliahkuliah para guru besar yang banyak dijadikan acuan. Generasi kedua di bawah Purnadi dan Soerjono, antara lain Achmad Ali pernah mencoba mengangkat kembali pembagian seperti yang disampaikan oleh Purnadi dan Soerjono, namun dalam pengklasifikasiannya, ia juga terlihat tidak konsisten. Ia membedakan ilmu hukum dalam tiga klasifikasi, yaitu Begriffenwissenschaft, Normwissenschaft, dan Tatsachenwissenschaft, tetapi guru besar dari Fakultas Hukum Universitas Hasanuddin ini memberi contoh klasifikasi tersebut dengan menyebutkan mata kuliah-mata kuliah (bukan dengan cabang-cabang keilmuan) dan entah mengapa pengajaran mata kuliah filsafat hukum dimasukkannya dalam klasifikasi yang pertama. ${ }^{14}$ Pengklasifikasian demikian berpotensi menggiring pembaca untuk memasukkan filsafat hukum sebagai bagian dari ilmu hukum tentang pengertian (Begriffenwissenschaf).

Bangunan disiplin hukum yang tidak terstruktur tentu sangat mengganggu pemikir sekelas Arief. Bagaimana mungkin para ahli hukum di Indonesia dapat membangun dan mengembangkan

politik hukum, filsafat hukum, dan ilmu hukum (dengan tiga cabangnya itu, berarti teori hukum lebih luas daripada filsafat hukum). Namun, justru pada halaman yang sama (vii), Purnadi dan M. Chidir menuliskan ilmu hukum (teori hukum), yang mencakup ilmu kaedah, pengertian dan keyataan hukum. Artinya, pada sistematika disiplin hukum yang lama, teori hukum itu artinya sama dengan ilmu hukum dalam arti luas. Padahal, pengertian ini tidak sepenuhnya tepat karena dalam sistematika yang dikemukan oleh Meuwissen, Bruggink, dan Arief, ilmu tentang norma ini akan banyak berkaitan dekat dengan ilmu hukum dogmatis, sedangkan ilmu tentang pengertian akan bersentuhan erat dengan teori (ilmu) hukum. Bandingkan juga dengan terjemahan berbeda oleh Muhamad Arifin atas buku yang sama karya W. Friedmann. Dalam buku terjemahan yang dipecah menjadi tiga jilid itu, Arifin memberi judul bukunya: Teori dan Filsafat Hukum (Jakarta: Rajawali 1990). Ini berarti, istilah legal theory meliputi sekaligus teori hukum dan filsafat hukum.

14 Ahmad Ali, Menguak Teori Hukum (Legal Theory) dan Teori Peradilan (Judicial Jurisprudence) Termasuk Interpretasi Undang-Undang (Legisprudence) (Jakarta: Kencana, 2009), hlm. 18-19. 
pengembanan hukum teoretis apabila struktur keilmuan hukum itu sendiri tidak mereka kuasai atau sepakati? Arief dapat dikatakan hadir untuk menertibkan kesimpangsiuran ini. Dalam salah satu diskusi dengan penulis, Arief tidak punya pretensi untuk mengatakan sistematika yang diintroduksi oleh ahli hukum sebelumnya itu keliru. Ia lebih memilih menyatakan bahwa sistematika seperti yang disampaikan oleh Purnadi dan Soerjono adalah pohon disiplin hukum sebelum abad ke-19, sementara ia menyodorkan versi termutakhir yang berlaku setelah abad ke-19.

Untuk mencerna pemahamannya tentang bangunan disiplin hukum yang terkini (state of the arts), Arief mulai dengan konsep pengembanan hukum, yang dimaknainya sebagai kegiatan manusia berkenaan dengan adanya dan berlakunya hukum di dalam masyarakat, yang meliputi kegiatan membentuk, melaksanakan, menerapkan, menemukan, menafsirkan, meneliti, dan secara sistematikal mempelajari dan mengajarkan hukum. Pengembanan hukum itu dapat dibedakan menjadi pengembanan hukum praktikal dan pengembanan hukum teoretikal. ${ }^{15}$ Bangunan displin hukum itu terjadi pada pengembanan hukum teoretikal (teoretis).

Dalam pengembanan hukum teoretis, terdapat area ilmuilmu hukum yang berobjek telaah tatanan hukum nasional dan internasional. ${ }^{16}$ Ilmu-ilmu hukum ini ada yang berkarakter normatif dan empiris. Dikatakan berkarakter normatif karena ia berangkat dari perspektif internal dengan objek telaah hukum sebagai SollenSein. Di sini akan hadir ilmu hukum yang praktikal-normologis, yang bersentuhan dengan interpretasi dan sistematisasi bahan hukum serta teori perundang-undangan, penemuan hukum, dan argumentasi hukum. Di sisi lain ada ilmu hukum empirikal yang berperspektif eksternal, seperti perbandingan hukum, sosiologi hukum (objek telaahnya adalah hukum sebagai Sein-Sollen), sejarah hukum (objek

15 B. Arief Sidharta, "Pengembanan Hukum," dalam Bernard Arief Sidharta Penziarah Hukum, hlm. 131.

16 Bandingkan dengan pandangan John Austin yang memosisikan tatanan hukum internasional sebagai bukan hukum yang sebenarnya. John Austin, The Province of Jurisprudence Determined (Cambridge: Cambridge University Press, 1995), hlm. 20, 31-33, 109-110, 136. 
telaahnya adalah hukum dalam konteks waktu), antropologi hukum (objek telaahnya adalah hukum dalam konteks kultur), dan psikologi hukum.

Pada lapisan teori [ilmu] hukum ditekankan tentang objek telaah berupa tatanan hukum positif sebagai sistem. ${ }^{17}$ Teori [ilmu] hukum ini membahas tentang ajaran hukum (analisis pengertian hukum; analisis asas-kaidah, figur (pranata), dan sistem hukum; analisis konsep-konsep yuridis; dan hubungan antar-konsep yuridis). Juga dibahas tentang hubungan hukum dan logika (analisis teori argumentasi yuridis dan logika deontik). Terakhir, mengenai metodologi, yang mencakup ajaran ilmu (epsitemologi ilmu hukum, metode penelitian dan analisis hukum, dan struktur-struktur yuridis) dan ajaran metode praktik hukum (teori pembentukan hukum dan teori penemuan hukum yang meliputi teori interpretasi dan konstruksi hukum).

Lapisan paling abstrak adalah filsafat hukum. Cabang ini merupakan bagian dari dan dipengaruhi oleh filsafat umum. Filsafat hukum juga meresapi teori ilmu hukum dan ilmu-ilmu hukum. Objek telaahnya adalah hukum sebagai demikian (the law as such). Selanjutnya, filsafat hukum juga membahas pokok kajian dwitunggal pertanyaan inti, yaitu landasan daya ikat hukum serta landasan penilaian keadilan dari hukum (norma kritik).

Untuk sampai pada persetujuannya menggunakan skema dari D.H.M. Meuwissen, ${ }^{18}$ ia sudah terlebih dulu menelaah posisi kefilsafatan dari keilmuan hukum itu. Dalam hal inilah ia sangat

17 Di sini sebenarnya Meuwissen memiliki perbedaan pandangan dengan J.J.H. Bruggink. Menurut Bruggink, teori hukum tidak selalu mengacu ke hukum positif karena ada juga jenis teori hukum reflektif (kontemplatif). J.J.H. Bruggink, Refleksi tentang Hukum: Pengertian-Pengertian Dasar dalam Teori Hukum, terj. B. Arief Sidharta (Bandung: Citra Aditya Bakti, 2015), hlm. 170-176,

18 Dalam penerjemahan tulisan-tulisan Meuwissen tersebut, Arief menampilkan tiga skema buatannya sendiri mengenai pengembanan hukum, pembentukan undang-undang, dan penemuan hukum. Skema-skema ini didesain oleh Arief secara cermat dan detail, yang menunjukkan hasratnya yang mendalam untuk memudahkan para pembaca mencerna karya terjemahannya. 
terpengaruh oleh Paul Scholten. Ia bahkan pernah menyatakan bahwa ia tidak menolak jika dikatakan disertasinya berisi pemikiran Scholten yang diterapkan untuk kondisi Indonesia. ${ }^{19}$ Paparan yang paling gamblang pada akhirnya ditunjukkan oleh Arief saat ia menerjemahkan dengan sangat baik tulisan J.J.H. Bruggink. Dengan demikian, tiga nama di atas, yakni Meuwissen, Scholten, dan Bruggink dapat disebut sebagai peletak dasar pemikiran Arief dalam pengembanan hukum teoretis. Dari pilihan tokoh-tokoh ini sesungguhnya tidak terlalu mengejutkan kecenderungan berpikir beliau dalam menggiring persoalan untuk menjawab pertanyaan tentang apa fondasi, sifat, dan ciri khas ilmu hukum itu?

Demikianlah, penelusuran Arief sampai pada kesimpulan bahwa cabang dari disiplin hukum yang disebut dengan ilmu hukum dogmatis (dogmatika hukum) itu termasuk dalam kategori ilmu praktis, lebih spesifik lagi adalah ilmu praktis normologis yang otoritatif. Perjalanan untuk sampai kepada posisi pandangan ini tidaklah singkat, yang semua tertuang di dalam disertasinya yang ditulis dalam kurun waktu cukup lama. ${ }^{20}$

Kegelisahan yang mendorongnya untuk menulis topik disertasi tersebut tidak mungkin menghinggapi sembarang penstudi hukum. Ia memilih topik yang jarang dilirik karena memang berisiko jika tidak

19 Pada November 2015, bertepatan dengan saat Arief Sidharta wafat di Bandung, penulis artikel ini (Shidarta) sedang berada di Amsterdam atas undangan Fakultas Hukum Universitas Amsterdam sebagai pembicara kunci dalam simposium untuk menggali pemikiran Paul Scholten. Di simposium ini penulis memaparkan pemikiran-pemikiran Arief Sidharta di hadapan sejumlah ahli hukum Belanda dan Indonesia dan mendapat konfirmasi betapa dekat pandangan Arief dengan Scholten. Makalah dalam simposium ini dapat dilihat dalam: Shidarta, "In Search of Scholten's Legacy: the Meaning of the Method of 'Rechtsvinding' for the Current Indonesian Legal Discourse,” https://www.paulscholten.eu/research/ article/in-search-of-scholtens-legacy/, akses 20/10/2020.

20 Arief Sidharta sempat kehilangan bahan-bahan disertasi yang disimpannya dalam komputer jinjingnya karena komputer itu dicuri pada 1993. Baru tiga tahun kemudian ia dapat menuntaskan studi doktoralnya. Ia mengaku, kehilangan bahan-bahan disertasi tersebut membuatnya harus menulis ulang pemikirannya, dan anehnya, dengan cara itu ia justru menemukan banyak kemudahan menuangkan gagasan-gagasan yang lebih baru. 
menemukan pembimbing yang berkompeten. Ia mengaku sangat terinspirasi oleh pertanyaan tentang apakah hukum itu adalah ilmu? Wacana ini jelas bukan isu baru karena sudah dipertanyakan oleh sejumlah ahli hukum, sebagaimana terbaca melalui pertentangan pemikiran antara J.H. von Kirchmann (1848), A.V. Lundstedt (1932), G.E. Langemeijer (1972) dan L.M. Friedman (1975) berhadapan dengan pemikiran tokoh-tokoh yang tidak kalah seniornya seperti Paul Scholten (1945), R. Kranenburg (1955), J.W. Harris (1979), J.J.M. van der Ven (1983), dan M. van Hoecke (1984). Terakhir ia juga mencermati pandangan Carel Smith dan A. Soeteman berkenaan dengan persoalan ini. Semua konstelasi pemikiran itu ia telaah. Ini berarti Arief benar-benar memahami latar belakang historis dan filosofis dari duduk persoalan yang ingin beliau kaji.

Namun, obsesi Arief sebenarnya tidak berhenti hanya sebatas mengklarifikasi posisional keilmuan hukum. Obsesi beliau untuk memilih topik disertasinya terlihat dari anak judul disertasinya, yaitu untuk menjadikan hasil penelitiannya sebagai landasan pengembangan ilmu hukum nasional Indonesia. Hal ini juga secara eksplisit diungkapkannya pada rumusan kedua permasalahan disertasinya itu, yakni apa ciri khas ilmu hukum nasional Indonesia? Motivasinya yang sangat kuat untuk menemukan karakteristik ilmu hukum nasional Indonesia ini tidak sekadar basa-basi karena akhirnya dibuktikannya melalui pernerbitan bukunya yang terakhir sebelum beliau berpulang ke haribaan Sang Khalik, yaitu sebuah buku berjudul Ilmu Hukum Indonesia.

\section{Penalaran Hukum}

Apabila seseorang berbicara tentang filsafat hukum, area ini sudah banyak peminatnya. Mereka yang tidak berlatar belakang hukum sekalipun, seperti penstudi filsafat, juga memiliki minat yang sangat besar terhadap hukum. Lain halnya dengan arena teori [ilmu] hukum yang lebih jarang dijelajahi secara serius. Padahal, basis untuk mempelajari ilmu hukum sangat penting dibangun dari lapisan tengah disiplin hukum tersebut. Arief menyadari hal ini. Baginya, 
ilmu hukum dogmatis itu terlalu konkret, sedangkan filsafat hukum terlalu abstrak. Jembatan di antara keduanya adalah teori [ilmu] hukum.

Dari berbagai tema sentral teori [ilmu] hukum, Arief menaruh perhatian khusus pada penalaran hukum. Untukituia menerjemahkan sejumlah tulisan penting tentang penalaran hukum atau argumentasi hukum, salah satunya tulisan M. Henket. ${ }^{21}$ Ia pernah menyatakan harapannya untuk dapat "membumikan" teknik-teknik penalaran hukum ini agar dapat mudah dipraktikkan oleh para pengemban hukum praktis.

Tatkala berkesempatan membimbing penulisan disertasi penulis berjudul "Karakteristik Penalaran Hukum dalam Konteks Keindonesiaan" (2004), ${ }^{22}$ Arief memperlihatkan antusiasmenya yang luar biasa terhadap topik tersebut. Namun, tatkala disertasi ini selesai ditulis dan dipertahankan di hadapan penguji, ia menilai karya itu masih terlalu filosofis. "Tidak apa, kita cari orang lain lagi yang bisa membumikannya," ujarnya ketika itu. Sampai akhir hayatnya Arief mungkin belum sempat membimbing peneliti lain guna menggarap bidang kajian ini menjadi lebih operasional dalam wujud sebuah proyek disertasi. Di sisi lain, ia ingin mata kuliah penalaran hukum itu sendiri dapat eksis di dalam kurikulum fakultas hukum, paling tidak di beberapa perguruan tinggi. Untuk itu penulis dalam kurun waktu cukup lama diminta menemaninya mengajarkan mata kuliah tersebut langsung, khususnya di Fakultas Hukum Universitas Katolik Parahyangan. Dalam kenyataannya, beliau tidak pernah hadir di ruang kuliah dan sejak awal menyerahkan penggarapan mata kuliah itu sepenuhnya kepada penulis. Sebulan sebelum wafat, Arief bersama

21 M. Henket, Teori Argumentasi dan Hukum, terj. B. Arief Sidharta (Bandung: Laboratorium Hukum Fakultas Hukum Universitas Katolik Parahyangan, 2003).

22 Buku ini dicetak ulang dengan judul baru: Shidarta, Hukum Penalaran dan Penalaran Hukum (Yogyakarta: Genta Publishing, 2012). Shidarta adalah mahasiswa yang dibimbing secara langsung oleh Arief saat kuliah dan menyusun disertasi doktoralnya di Universitas Katolik Parahyangan (20002004). Mereka berdua juga terlibat berbagai kegiatan akademik, antara lain mengajar bersama dan mendirikan Asosiasi Filsafat Hukum Indonesia (AFHI). 
dengan penulis masih sempat menjadi pembicara di sebuah pelatihan penalaran hukum untuk para ahli hukum yang bekerja di Komisi Yudisial Republik Indonesia dan ia menyatakan kebahagiaannya mendapati kajian penalaran hukum itu ternyata telah makin "membumi" karena bisa dioperasionalkan dalam rangka mengkritisi dan menganotasi secara sistematis putusan-putusan pengadilan. ${ }^{23}$

Penalaran hukum yang membumi, yang dimaksud oleh Arief, adalah penalaran dalam rangka menyelesaikan kasus-kasus konkret. Gambarannya kurang lebih seperti tulisan Gr. van der Borght dan J.D.C. Winkelman yang pernah diterjemahkan dan dipublikasikannya pada tahun $1994 .{ }^{24}$ Kedua penulis Belanda tersebut menawarkan tujuh langkah dalam penyelesaian kasus, yang notabene sebenarnya adalah langkah-langkah penalaran hukum juga. Ketujuh langkah itu meliputi kegiatan: (1) meletakkan kasus dalam sebuah peta atau memaparkan kasus dalam sebuah ikhtisar mengenai duduk perkara dari suatu kasus (skematisasi); (2) menerjemahkan kasus itu ke dalam peristilahan yuridis (pengkualifikasian); (3) menyeleksi aturan-aturan hukum yang relevan; (4) menganalisis dan menafsirkan (interpretasi) terhadap aturan-aturan hukum itu; (5) menerapkan aturan-aturan hukum pada kasus; (6) mengevaluasi dan menimbang (mengkaji) argumen-argumen dan penyelesaian; dan (7) merumuskan(formulasi) penyelesaian.

Tentu saja, penalaran seperti ini dalam praktiknya sudah dijalankan oleh para penstudi dan aparat penegak hukum(khususnya hakim), melalui proses learning by doing; sementara terdapat pakem-pakem keilmuan hukum yang sebenarnya dapat menghindarkan mereka dari kesimpulan yang melompat (jumping to conclusion). Apabila di berbagai negara maju kajian penalaran hukum ini telah menyedot perhatian dari para teoretisi hukum, di Tanah Air topik ini terbilang baru diminati segelintir orang. Tidak dapat disangkal, tulisan-tulisan

23 Lihat: Anonim, "Pelatihan Penalaran Hukum untuk Komisi Yudisial," https: / / business-law.binus.ac.id/2015 / 10/22 / pelatihan-penalaran-hukumuntuk-komisi-yudisial/, akses 23/10/2020.

24 Gr. van der Borght dan J.D.C. Winkelman, "Penyelesaian Kasus," Jurnal Pro Justitia 1 (1994), hlm. 35-53. 
Arief, baik di dalam karyanya sendiri maupun terjemahan/saduran, merupakan sumbangsih yang luar biasa. Beliau adalah orang pertama yang mampu menempatkan penalaran hukum itu sebagai kajian teoretisi hukum, yang tersambung ke filsafat hukum dan ilmu hukum dogmatis. Dalam sebuah manuskrip yang tidak terpublikasi berjudul "Penalaran Hukum," Arief menjelaskan hal itu dengan kata-kata sebagai berikut: ${ }^{25}$

Tentang penalaran hukum atau argumentasi hukum,, H.Ph. Visser't Hooft dalam bukunya yang berjudul Filosophie fan de Rechtswetenschap mengemukakan pokok-pokok pikiran sebagai berikut: Dalam 'Algemeen Deel'-nya, Scholten membedakan: interpretasi undang-undang berdasarkan pemakaian bahasa, interpretasi sejarah undang-undang, interpretasi sistematikal, interpretasi sejarah hukum, kewibawaan (otoritas) putusan pengadilan, otoritas ilmu, pengacuan pada kebiasaan atau kelaziman dalam pergaulan, interpretasi sosiologikal, interpretasi teleologikal... Scholten melihat, dalam bentuk-bentuk penemuan hukum ini, sekian banyak 'faktor-faktor kewibawaan atau otoritas' bekerja atau berpengaruh, dan di antara mereka (maksudnya: tentang mereka) tidak dapat ditunjukkan adanya tatanan hierarkhial yang ajeg. Hukum tidak hanya mengenal satu sumber otoritas, melainkan banyak. Pemaparan argumentasi yuridikal menunjuk pada analisis Filsafat Hukum -- dengan kata lain, nilai-nilai apa, penetapan tujuan-tujuan dasar apa yang diinvestasikan (terkandung) dalam tatanan hukum? Yuris mendekati ketentuan yang dalam suatu kasus konkret berlaku sebagai hukum (yang mengikat secara sah) dari sudut suatu pengertian implisit tentang nilainilai hukum ini, dan pengertian ini memberikan kepadanya strategistrategi pengambilan putusannya.

Singkat kata, Arief meyakini berpikir yuridik adalah "Suatu cara berpikir tertentu, yakni terpola dan terarah dalam konteks sistem kaidah-kaidah hukum positif dan kenyataan kemasyarakatan, untuk memelihara stabilitas dan prediktabilitas demi menjamin ketertiban dan kepastian hukum, untuk menyelesaikan kasus konkret secara imparsial-objektif-adil-manusiawi." ${ }^{26}$ Rangkaian kata-kata di atas sangat khas Arief Sidharta, yakni penuh perhitungan dan makna. Dengan menyatakan "penalaran hukum sebagai cara berpikir tertentu”, memperlihatkan sikapnya yang menolak klaim kaum

25 B. Arief Sidharta, "Penalaran Hukum," manuskrip tidak diterbitkan, hlm. 7.

26 Sidharta, "Penalaran Hukum," hlm. 2. 
Crits bahwa penalaran hukum itu tidak ada yang unik. ${ }^{27}$ Kata-kata "terpola dan terarah dalam konteks sistem kaidah-kaidah hukum positif” menunjukkan pandangan Arief tentang sisi normatif dalam penalaran hukum. Kemudian ia menyebutkan kata "kenyataan kemasyarakatan” yang mengacu pada sisi empiris dalam penalaran hukum. Kedua sisi ini saling berdialektika: Sein-Sollen dan Sollen-Sein. Penggunaan kata-kata "memelihara stabilitas dan prediktabilitas demi menjamin ketertiban dan kepastian hukum” adalah nilai-nilai yang ingin dilekatkannya dalam penalaran hukum. Ini adalah aspek filosofis yang penting menurut Arief, yang boleh jadi dipengaruhi oleh atau tersambung dengan pemikiran Mochtar Kusuma-Atmadja. ${ }^{28}$ Kata-kata stabilitas (ketertiban) dan prediktibilitas (kepastian hukum) ini menjadi salah satu jargon dalam teori hukum pembangunan-nya Mochtar. ${ }^{29}$ Terakhir, frasa yang berbunyi "untuk menyelesaikan kasus konkret secara imparsial-objektif-adil-manusiawi” merupakan tujuan penalaran hukum itu, sebagai wujud penerapan ilmu hukum dogmatis sebagai ilmu praktis yang menjawab langsung kebutuhan masyarakat. Kendati demikian, Arief seperti ingin mengingatkan bahwa penalaran hukum tidak boleh lepas begitu saja dari nilai-nilai ideal (aksiologis) yang imparsial, objektif, adil, dan manusiawi.

Nilai-nilai ini terus diperjuangkannya, tidak sebatas tinta di atas kertas. Ia misalnya pernah menyuarakan ketidaksetujuannya atas pidana mati di dalam sistem hukum Indonesia saat diminta menjadi ahli di Mahkamah Konstitusi dalam perkara Nomor 2/PUU-V / 2007 dan Nomor 3 / PUU-V/2007. Pada dua alinea terakhir keterangannya

27 Baca: A.C. Hutchinson dan P.J. Monahan, "Law, Politics, and the Critical Legal Scholars: the Unfolding Drama of American Legal Thought," Standford Law Review, 36, 1 \& 2 (1984), hlm. 199-245.

28 Mochtar Kusuma-Atmadja dan B. Arief Sidharta, Pengantar Ilmu Hukum: Suatu Pengenalan Pertama Ruang Lingkup Berlakunya Ilmu Hukum, Buku I (Bandung: Alumni, 2009), hlm. 49-53. Patut dicatat bahwa Arief Sidharta cukup lama bersama dengan Mochtar Kusuma-Atmadja sebagai teamteaching mengasuh mata kuliah Pengantar Ilmu Hukum.

29 Mochtar Kusuma-Atmadja, "Fungsi dan Perkembangan Hukum dalam Pembangunan Nasional”, dalam Konsep-Konsep Hukum dalam Pembangunan: Kumpulan Karya Tulis Prof. Dr. Mochtar Kusumaatmadja, ed. H.R. Otje Salman dan Eddy Damian (Bandung: Alumni, 2002), hlm. 1-17. 
di hadapan hakim konstitusi, Arief seperti mengartikulasi kembali seperti apa seharusnya penalaran hukum yang dipandangnya imparsial-objektif-adil, dan manusiawi itu. ${ }^{30}$

Dalam penciptaannya, tiap manusia dilengkapi oleh Tuhan dengan akal budi dan nurani yang memungkinkan manusia memiliki kemampuan untuk membedakan yang benar dari yang salah, baik dari buruk, yang jahat dari yang tidak jahat, yang adil dari tidak adil, yang manusiawi dari tidak manusiawi. Berdasarkan keyakinan tentang benar-salah dan baik-buruk itulah manusia akan menentukan sendiri tentang apa yang harus dan akan dilakukannya atau tidak, dan manusia bertanggung jawab sepenuhnya berkenaan dengan pilihan tindakan yang dilakukan atau tidak dilakukannya. Artinya, manusia memiliki kebebasan untuk berkemauan dan bertindak sesuai atau tidak sesuai dengan kehendaknya itu. Jadi, ketika para pembentuk undang-undang memutuskan untuk menetapkan ancaman hukuman mati, maka itu adalah kehendak dan putusan manusia yang terlibat dalam pengambilan putusan itu. Juga ketika seorang hakim memutuskan untuk menjatuhkan hukuman mati sesuai dengan undangundang yang berlaku, maka itu pun adalah putusan hakim tersebut, bukan kehendak dan putusan Tuhan. Hanya kematian yang terjadi secara alami saja yang dapat dikatakan sebagai kehendak Tuhan. Pada analisis terakhir, masalah hukuman mati itu langsung berkenaan dengan manusia dengan segala ketidaksempurnaan dan kekurangannya. Sehubungan dengan ini, dalam melaksanakan perundang-undangan pidana dan dalam rangka meninjau kembali bentukbentuk hukuman dalam RUU KUHP, mungkin ada gunanya bagi kita untuk sejenak merenungkan ucapan Sir Thomas Noon Talfourd (dalam "The Family of Man"): "Fill the seats of justice With good men, not so absolute in goodness as to forget what human frailty is".

\section{E. Ilmu Hukum Indonesia}

Sejak Revolusi Perancis, ilmu hukum telah kehilangan karakter universalnya. Dengan demikian, ketika seseorang berbicara tentang ilmu hukum dogmatis, ilmu itu akan bakal terkukung dalam koridor nasionalitas yang memiliki fondasi dan arah pengembangannya sendiri-sendiri. Atas dasar pemikiran ini, Arief menggagas apa yang disebutnya dengan ilmu hukum nasional Indonesia.

Buku terakhir yang diterbitkan dan kemudian direvisi dua bulan

30 Baca polemik ini dan sikap Arief Sidharta dalam: Todung Mulya Lubis dan Alexander Lay (ed.), Kontroversi Hukuman Mati (Jakarta: Penerbit Buku Kompas, 2009). 
sebelum ia wafat telah dipersiapkan untuk menjawab gagasannya itu. Sebuah gagasan yang sudah tercetus sejak jauh hari, paling tidak sebagaimana tercermin dari topik disertasinya. Judul lengkap dari buku ini adalah "Ilmu Hukum Indonesia: Upaya Pengembangan Ilmu Hukum Sistematik yang Responsif terhadap Perubahan Masyarakat." Kata "sistematik" (sistematis) ${ }^{31}$ dalam judul tersebut memperlihatkan sikap Arief untuk tetap percaya pada visi keilmuan hukum sebagai ilmu yang sistematis.

Kata "responsif" yang digunakan di sini mengingatkan kita pada terminologi serupa yang digunakan oleh Nonet dan Selznick. ${ }^{32}$ Ternyata Arief tidak benar-benar sempat mengelaborasi konsep responsif seperti yang dikehendaki Nonet dan Selznick. Bab IX atau bab terakhir dari buku Ilmu Hukum Indonesia, yang diberi judul "Paradigma Ilmu Hukum Indonesia” sama sekali tidak muncul kata "responsif”. Bab ini hanya berjumlah 20 halaman dari keseluruhan 177 halaman bukunya tersebut. Isinya juga merupakan pemuatan ulang dari Bab V huruf C dari buku disertasi beliau yang terbit 14 tahun sebelumnya. Artinya, Arief belum benar-benar all-out menuangkan pikirannya untuk bab yang seharusnya menjadi inti dari buku tersebut. Kegalauannya menyaksikan manuver berhukum yang tidak elok pada sepuluh tahun terakhir dari kehidupannya, sebagaimana kerap diutarakannya kepada rekan-rekan dekatnya, selayaknya sudah menjadi materi yang cukup untuk direfleksikannya tentang apakah hukum sistematik yang responsif itu masih jauh panggang dari api. Uraian tentang hukum responsif justru pernah muncul di

31 Salah satu ciri diksi dari Arief Sidharta adalah penggunaan akhiran "ik" dan "al" untuk kata-kata sifat, seperti "sistematik" atau "sistematikal". Semua pilihan kata ini sangat diperhitungkan, khususnya ketika ia harus menerjemahkan suatu istilah yang sulit dicari padanannya dari bahasa asing ke dalam bahasa Indonesia.

32 Phillipe Nonet dan P. Selznick, Law and Society in Transition: toward Responsive Law (New Brunswick: Transaction Publishers, 2009), hlm. 73-114. Dalam sebuah pembicaraan dengan penulis, Arief pernah menyampaikan sinyalemen bahwa sistem hukum Indonesia jangan-jangan tidak bisa berkembang dengan baik karena kita melakukan lompatan dari represif ke responsif, tidak melewati anak tangga ke otonomius terlebih dahulu. 
dalam disertasinya dan diulas khusus dalam Bab II. ${ }^{33}$ Ceruk tersebut tentu punya alasan tersendiri, termasuk salah satunya adalah faktor kesehatan yang kerap menginterupsi aktivitas beliau.

Ilmu hukum [nasional] Indonesia di mata Arief adalah ilmu hukum yang dapat membawa Indonesia menjadi negara hukum yang sesuai dengan cita hukum Pancasila. Arief sangat meminati kajian tentang Pancasila ini. Selain tulisannya yang berjudul "Filsafat dan Ideologi Pancasila” yang dimuat di Jurnal Pro Justitia (No. 1, 1994), beliau pernah menulis sebuah manuskrip yang tidak dipublikasikan, berjudul "Filsafat Hukum Pancasila". Ia juga menyunting kumpulan lengkap tulisan-tulisan Soediman Kartohadiprodjo ("Pancasila sebagai Pandangan Hidup Bangsa Indonesia”), yang sudah cukup meneguhkan kedalaman pemahaman dan komitmen beliau pada Pancasila. Di dalam disertasinya, ia membuat ragaan cukup detail untuk melukiskan seperti apa negara hukum Pancasila tersebut. ${ }^{34}$ Ia memimpikan akan lahir negara hukum Pancasila pada abad ke21. Negara hukum yang dimaksud adalah negara yang bercirikan demokrasi dan kesejahteraan. Hukum dibuat oleh suatu legitimasi otoritas publik guna melahirkan kesejahateraan rakyat, keadilan, dan kepastian hukum. Ia menulis sebagai berikut: ${ }^{35}$

Sebab, dengan Proklamasi Kemerdekaan dan terbentuknya negara Republik Indonesia sebagai negara nasional, sesungguhnya paradigma Ilmu Hukum di Indonesia sudah berubah karena perubahan objek telaahnya, yang mengubah medan berkiprahnya (dari hukum kolonial menjadi hukum nasional), dan dengan itu masalah-masalah fundamental dalam bidang hukum yang harus ditangani, dan cara menanganinya juga harus berubah.

Arief tidak melahirkan suatu teori baru tentang pembangunan ilmu hukum nasional Indonesia itu, tetapi ia menawarkan lima butir pikiran yang, menurutnya, mungkin dapat dikembangkan untuk

33 Bernard Arief Sidharta, Refleksi tentang Struktur Ilmu Hukum: Sebuah Penelitian tentang Fundasi Kefilsafatan dan Sifat Keilmuan Ilmu Hukum sebagai Landasan Pengembangan Ilmu Hukum Nasional Indonesia (Bandung: Mandar Maju, cetakan kedua, 2000), hlm. 50-52.

34 Sidharta, Refleksi tentang Struktur Ilmu Hukum, hlm. 82 dan 83.

35 Sidharta, Refleksi tentang Struktur Ilmu Hukum, hlm. 180. 
mewujudkan paradigma Ilmu Hukum Nasional Indonesia. Ia berkalikali menyebut kata "paradigma" karena ia memang melihat ada problem paradigmatik dari ilmu hukum. Problem itu timbul karena dewasa ini hukum dan ilmu hukum seakan berkiprah dalam dunia tertutup yang terpisah dari dan tidak bersentuhan dengan dunia kenyataan kemasyarakatan. Dari sudut pandangnya, "Diskrepansi ini menyebabkan hukum dan ilmu hukum tidak lagi dimengerti oleh para warga masyarakat, yang hingga derajat tertentu ikut mengakibatkan krisis otoritas, kemerosotan hukum serta pandangan negatif terhadap hukum dan ilmu hukum, dan bersamaan dengan itu menurunnya minat orang muda untuk memasuki pendidikan tinggi hukum." Lima konsep kunci guna memunculkan paradigma baru tersebut mencakup cita hukum Pancasila, konsepsi hukum, tujuan hukum pengayoman, konsepsi negara, dan konsepsi ilmu hukum. ${ }^{36}$

Tatkala Arief berbicara tentang hukum nasional Indonesia, ia mencoba untuk membawa wacana ke arah politik hukum berupa pembangunan substansi hukum, tepatnya tata hukum nasional Indonesia, sebagaimana terlihat dalam Gambar 1. Inti dari tata hukum nasional itu adalah cita hukum Pancasila. Pada lapisan di luar itu terdapat asas-asas hukum nasional. Lapisan berikutnya adalah aturan hukum positif, seperti undang-undang, yurisprudensi, dan hukum kebiasaan. Di luar itu terdapat lapisan berikutnya berupa perilaku atau praktik hukum dari subjek-subjek hukum. Lapisan terluar ini berinteraksi dengan area-area politik, ekonomi, sosial, budaya, dan teknologi, yang menjadi landasan dan susunan kemasyarakatan. Lapisan ini juga secara ajeg dipengaruhi oleh hukum kolonial (civil law system) dan hukum anglo-saxon (common law system). Sementara itu, secara internal tata hukum nasional itu, mulai dari lapisan asasasas sampai ke lapisan perilaku, dipengaruhi lagi oleh hukum adat dan hukum agama.

36 Sidharta, Refleksi tentang Struktur Ilmu Hukum, hlm. 180-196. Ternyata sistematika yang sama dapat dilihat dalam B. Arief Sidharta, Ilmu Hukum Indonesia: Upaya Pengembangan Ilmu Hukum Sitematik yang Responsif terhadap Perubahan Mayarakat (Bandung: Unpar Press, 2016), hlm. 146-161. 


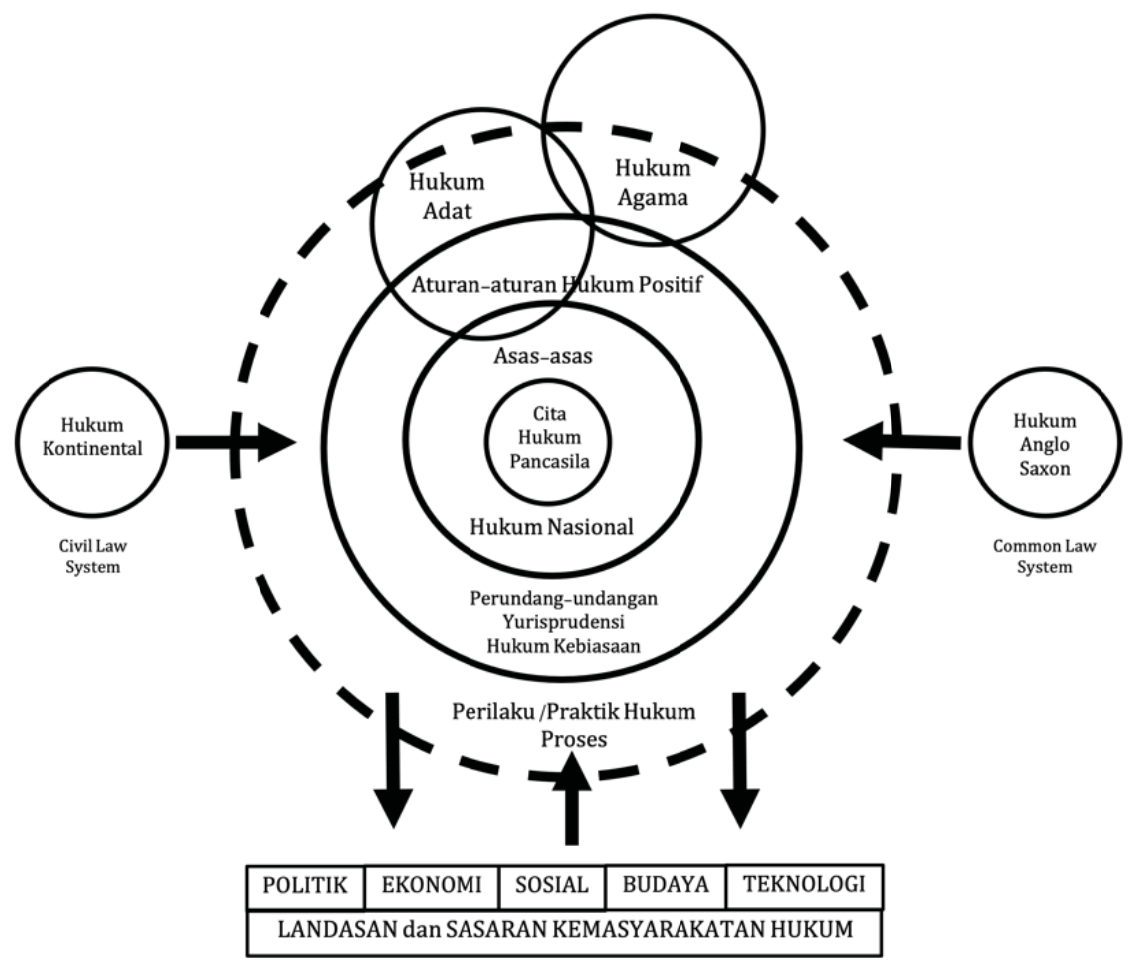

Gambar 1. Tata Hukum Nasional Indonesia ${ }^{37}$

Pertanyaan yang sangat menarik untuk diajukan kepada Arief adalah tentang sikapnya berkenaan dengan pluralisme hukum di Tanah Air. Apakah ia lebih cenderung ke wajah tata hukum yang secara kuat memperlihatkan pluralisme hukum (strong legal pluralism) atau secara lemah menjadikan pluralisme hukum tidak boleh mengalahkan hukum negara (weak legal pluralism). ${ }^{38}$ Tidak dapat disangkal jika sekilas muncul pandangan bahwa Arief lebih bergerak ke kutub pluralisme hukum yang lemah. Kalaupun timbul konklusi seperti itu, tidaklah berarti Arief kurang menghormati eksistensi hukum-hukum adat. Sebagai eks pengajar hukum adat, ia cukup fasih menjelaskan arti penting hukum adat sebagai landasan pembangunan tata hukum nasional.

37 Sidharta, Refleksi tentang Struktur Ilmu Hukum, hlm. 83.

38 J. Griffiths, "What is Legal Pluralism?", Journal of Legal Pluralism and Unofficial Law, 18, 24 (1986), hlm. 1-55. 
Dalam banyak kesempatan, Arief seolah mengartikulasi pemikiran Soediman Kartohadiprodjo pada era 1963, yang menyatakan bahwa hukum adat hendaknya digunakan sebagai inti hukum nasional Indonesia. Apalagi karena ternyata titik pangkal pemikiran yang terdapat di belakang hukum adat itu membenarkan isi pikiran yang diberikan pada Pancasila sebagai sumber kehidupannya, yaitu Bhinneka Tunggal Ika. Soediman menulis: ${ }^{39}$

Ini berarti, bahwa dalam bidang hukum kit aharus berpikir secara Hukum Adat. Adalah suatu jasa besar dari alm. Prof. Mr. C. van Vollenhoven untuk -- enam puluh tahun lalu -- meraba adanya pemikiran dalam Hukum Adat itu yang lain dari pada yang lain. Karenanya, sering dianjurkan olehnya kepada murid-muridnya dan siapa saja yang tersangkut dengan Hukum Adat, kalau mempelajari Hukum Adat, supaya jangan memandang Hukum Adat itu dengan kacamata Romawi atau kacamata (hukum) Barat, tetapi dalam pada itu harus mempergunakan "kacamata Hukum Adat". Tetapi belum pernahlah beliau, pun murid-muridnya memberitahukan bagaimana sifatnya kaca yang dipakai untuk membikin kacamata itu, warnanya biru, atau kuning, atau bagaimana; bagaimana diasahnya, cylindris, convex, concaaf, atau bagaimana.

Pandangan Soediman seperti halnya diadopsi oleh Arief, bahwa "sifat kaca yang dipakai untuk membikin kacamata" hukum adat yang dipersoalkan dalam kutipan di atas, sudah terjawab melalui cita hukum Pancasila tersebut. Secara eksplisit, Soediman meneruskan pernyataannya: ${ }^{40}$

Kalau begitu, maka Pancasila ini merupakan soko guru dari pikiran, filsafat, yang merupakan dasar pikiran Hukum Adat dan dengan demikian Bung Karnolah yang dapat menemukan sifatnya kaca yang menjadi bahan kacamata "Hukum Adat" itu, yang van Vollenhoven dengan murid-muridnya tidak dapat menemukannya. Dengan demikian, maka sekarang kita, dalam menjalankan Hukum Adat, dapat berpikir lebih sistematis lagi dari yang sudah-sudah, karena sekarang sudah kita ketahui kaca apakah yang kita pakai dalam "Kacamata Hukum Adat" itu.

Kekuatan dari usulan Arief pada satu sisi terletak pada penjelasannya tentang cita hukum Pancasila, kendati tidak orisinal datang

39 Kartohadiprodjo, dkk., Prof. Mr. Soediman Kartohadiprodjo tentang Pancasila, hlm. 248. Pernyataan ini diambil dari tulisan pendek Soediman berjudul "Pancasila dan Hukum" yang diberi tanggal 8/2/1963.

40 Kartohadiprodjo, dkk., Prof. Mr. Soediman Kartohadiprodjo tentang Pancasila, hlm. 249. 
dari pandangannya sendiri. Lagi-lagi dalam konteks ini sulit untuk melepaskan sosok Soediman dari pemikiran Arief. ${ }^{41}$ Bedanya adalah pada diri Arief, semua pembahasan tentang tata hukum nasional Indonesia sebagai produk utama dari ilmu hukum Indonesia tersebut sudah diberi fondasi kefilsafatan dan sifat keilmuan ilmu hukum. Inilah yang luput dari jejak-jejak pemikiran Soediman, yang sebenarnya juga dalam banyak hal menarik untuk diberikan catatan. ${ }^{42}$ Arief telah berusaha melengkapi pemikiran guru sekaligus mentornya tersebut. Ini pula janji yang ingin ia tunaikan sejak penelitian disertasinya.

Menurutnya, cita hukum adalah gagasan, karsa, cipta, dan pikiran berkenaan dengan hukum atau persepsi tentang makna hukum, yang dalam intinya terdiri dari tiga unsur, yaitu keadilan, kehasilgunaan, dan kepastian hukum. Lebih lanjut ia menulis: ${ }^{43}$

Cita-hukum itu terbentuk dalam pikiran dan sanubari manusia sebagai produk berpadunya pandangan hidup, keyakinan keagamaan, dan kenyataan kemasyarakatan yang diproyeksikan pada proses pengkaidahan perilaku warga masyarakat yang mewujudkan tiga unsur cita-hukum tersebut tadi. Dalam dinamika kehidupan kemasyarakatan, cita- hukum akan mempengaruhi dan berfungsi sebagai asas umum yang mempedomani, norma kritik (kaidah evaluasi), dan faktor yang memotivasi dalam penyelenggaraan hukum (pembentukan, penemuan, dan penerapan hukum) dan perilaku hukum. Dirumuskan dan dipahaminya cita-hukum akan memudahkan penjabarannya ke dalam berbagai perangkat aturan kewenangan dan aturan perilaku, dan memudahkan terjaganya konsistensi dalam penyelenggaraan hukum. Dengan demikian, seyogianya tata hukum itu merupakan eksemplar ramifikasi cita-hukum ke dalam berbagai asas dan kaidah hukum yang tertata (tersusun) dalam sebuah sistem. Sejalan dengan itu, Ilmu Hukum mempelajari tatanan hukum sebagai sarana intelektual untuk memahami dan menyelenggarakan tatanan hukum tersebut, dalam pengembanannya seyogianya pula bertumpu dan mengacu pada cita-hukum itu.

41 Lihat pernyataan yang sama dalam Shidarta, "Posisi Pemikiran Bernard Arief Sidharta dalam Konfigurasi Aliran Pemikiran Hukum (Sebuah Diagnosis Awal)," dalam Bernard Arief Sidharta Penziarah Hukum, hlm. 46.

42 Mengenai catatan terhadap pemikiran Soediman Kartohadiprodjo, baca Shidarta, "Membaca Ulang Pemaknaan Keadilan Sosial dalam Gagasan Revolusi Hukum Soediman Kartohadiprodjo,” Veritas et Justitia, 1, 1 (2015), hlm. 20-38.

43 Sidharta, Refleksi tentang Struktur Ilmu Hukum, hlm. 185. Juga Sidharta, Ilmu Hukum Indonesia, hlm. 151. 
Mengenai apa yang menjadi esensi dari cita hukum tersebut, sekali lagi, terlihat pandangan Arief tentang ilmu hukum [nasional] Indonesia mendapat pengaruh sangat kuat dari Soediman Kartohadiprodjo. Cita hukum Pancasila tersebut berakar dalam pandangan hidup Pancasila, yang dengan sendirinya akan mencerminkan tujuan menegara dan nilai-nilai dasar yang tercantum dalam Pembukaan, Batang Tubuh serta Penjelasan Undang-Undang Dasar 1945. ${ }^{44}$ Ia menulis lagi sebagai berikut:

Pandangan hidup Pancasila bertolak dari keyakinan bahwa alam semesta dengan segala isinya, termasuk manusia, yang sebagai suatu keseluruhan terjalin sebagai harmonis, diciptakan oleh Tuhan. Kehadiran manusia di dunia dikodratkan dalam kebersamaan dengan sesamanya, namun tiap manusia memiliki kepribadian yang unik yang membedakan yang satu dari yang lain. Keseluruhan pribadi manusia dengan keunikannya masing-masing mewujudkan satu kesatuan, yakni kemanusiaan. Jadi, 'Kesatuan dalam Perbedaan'. Sebaliknya, dalam kebersamaan (kesatuan) itu tiap manusia individual warga kesatuan itu memperlihatkan kodrat kepribadian yang unik, yang berartinya terdapatnya perbedaan di dalam kesatuan kemanusiaan. Jadi 'Perbedaan dalam Kesatuan'. Kodrat kepribadian ini tidak dapat disangkal tanpa meniadakan kodrat kemanusiaannya... Selain itu, manusia juga tidak terlepas dari ketergantungan pada lingkungan alam dan Tuhan. Keberadaan dengan sesamanya serta ketergantungan pada alam dan Tuhan adalah struktur dasar yang hakiki dari keberadaan manusia. Struktur dasar kebersamaan dengan sesamanya dan keterikatan pada alam dan Tuhan ini dirumuskan dalam bentuk sila-sila dari Pancasila.

Kutipan di atas memperlihatkan bahwa cita hukum yang dimaksud oleh Arief adalah sebuah produk budaya mengikuti cara pandang manusia, masyarakat, dan bangsa Indonesia. Dari sini kemudian muncul sistem nilai Pancasila sebagai nilai-dasar (base-values) sekaligus nilai tujuan (goal-values). Pemikiran seperti ini sangat dekat dengan konsep jiwa rakyat (Volksgeist) yang dikemukakan mazhab sejarah. Cita hukum itu dipersepsikan berangkat dari pengalaman hidup bersama selama bergenerasi-generasi dan kemudian mengendap menjadi sistem nilai. Arief lalu menyimpulkan bahwa cita hukum

44 Sayangnya, Arief tidak memberi kritik mengenai posisi Penjelasan UndangUndang Dasar 1945 yang oleh Majelis Permusyawaratan Rakyat telah dilepaskan dari Undang-Undang Dasar dan sekadar dijadikan sebagai tafsir historis. 
Pancasila tersebut berintikan pada: (1) Ketuhanan Yang Maha Esa; (2) penghormatan atas martabat manusia; (3) wawasan kebangsaan dan wawasan Nusantara; (4) persamaan dan kelayakan; (5) keadilan sosial; (6) moral dan budi pekerti yang luhur; dan (7) partisipasi dan transparansi dalam proses pengambilan putusan publik. ${ }^{45}$ Tujuh rumusan ini diakui oleh Arief sebagai hasil perasannya atas pemikiran Soediman.

Dengan mempersepsikan cita hukum seperti ini, Arief meletakkan cita hukum ini baik sebagai nilai imanen yang menjadi nilai-dasar untuk mendeskripsikan sumber hukum material Indonesia, maupun sebagai nilai transenden yang mengarahkan ke mana tata hukum nasional Indonesia itu akan berproses. Tujuan hukum berdasarkan cita hukum Pancasila itu adalah untuk mewujudkan pengayoman bagi manusia, yakni melindungi manusia secara pasif dengan mencegah tindakan sewenang-wenang. Pelaksanaan pengayoman itu dilaksanakan dengan upaya mewujudkan: (1) ketertiban dan keteraturan yang memunculkan prediktabilitas; (2) kedamaian yang berketenteraman; (3) keadilan (distributif, komutatif, vindikatif, protektif); (4) kesejahteraan dan keadilan sosial; dan (5) pembinaan akhlakluhur berdasarkan Ketuhanan Yang Maha Esa. ${ }^{46}$ Tujuan hukum pengayoman, dengan demikian, jauh lebih luas daripada tujuan

45 Tujuh hal ini tidak jelas diberi predikat sebagai nilai atau asas. Apabila rangkaian tulisan itu dibaca secara kontekstual, maka dapat disimpulkan Arief memaknai tujuh hal itu sebagai nilai. Pada 22-24 Mei 1995, Badan Pembinaan Hukum Nasional (BPHN) mengadakan seminar nasional Temu Kenal Cita Hukum dan Penerapan Asas-Asas Hukum Nasional yang menampilkan beberapa tokoh, seperti R.M. Purwoto S. Gandasubrata, Awaloedin Djamin, M. Solly Lubis, Roesminah, H. Moh. Koesnoe, Sri Redjeki Hartono, Roeslan Abdulgani, Ismail Saleh, Abdulkadir Besar, Roeslan Saleh, Mochtar Kusumaatmadja, Oka Mahendra, dan Sri Soemantri Martosoewignyo. Apa yang diformulasikan oleh Arief Sidharta sebagai tujuh "nilai" di atas, dalam paparan para tokoh tersebut lebih dipahami sebagai asas-asas. Perbedaan gradasi antara nilai dan asas tersebut menunjukkan diskursus tentang cita hukum Indonesia masih belum terpetakan secara jelas. Tidak mengherankan apabila berbagai undangundang seperti berlomba-lomba mengintroduksi asas-asas hukum baru, padahal kemungkinan maksudnya adalah nilai-nilai.

46 Sidharta, Refleksi tentang Struktur Ilmu Hukum, hlm. 191. Juga Sidharta, Ilmu Hukum Indonesia, hlm. 159-160. 
hukum pada umumnya. Selain tujuan hukum yang konvensional mencakupi keadilan, kehasilgunaan, dan kepastian (prediktabilitas), Arief menambahkan tujuan-tujuan kedamaian, kesejahteraan, dan pembinaan akhlak luhur.

Jika pemikiran Arief harus dikritisi, titik kritik tersebut ada pada pengisian cita hukum yang menurutnya menjadi inti dari tata hukum sekaligus nilai dasar dan nilai tujuan dari gagasannya tentang ilmu hukum nasional. Keputusannya mendudukkan cita hukum di lingkaran terdalam tata hukum, bukanlah isu sentral dan hampir pasti tidak akan menuai bantahan dari pihak manapun (kecuali segelintir orang yang menolak eksistensi dasar negara Pancasila). Isu yang ditunggu-tunggu pembaca yang kritis adalah eksplanasi Arief tentang substansi cita hukum tersebut dan inilah yang belum sempat dielaborasinya secara terstruktur. Ia seakan terjebak pada sudut ruangan diskursus yang kurang lebih sama seperti dialamatkan oleh Kelsen atau Nawiasky ketika mereka ditantang mengungkapkan isi dari konsep Grundnorm atau Staatsfundamentalnorm. Butir-butir yang sempat ia kemukakan boleh jadi dipandang sebagai jawaban sementara, tetapi tentu tidak mungkin sesederhana itu.

Dengan modal kognitif yang dimilikinya seusai membedah pemikiran Peursen, Scholten, Meuwissen, Bruggink, dan lain-lain, Arief pasti mampu memperbincangkan topik ini secara mendalam. Tapi, sayang sekali Arief tidak cukup punya waktu (atau mungkin energi) menempatkan secara rasional dan sistematis semua nilai dan/atau asas yang telah diajukannya ke dalam konfigurasi kaidah dan meta-kaidah hukum, berbaju ilmu hukum Indonesia. Jika ini dilakukan, niscaya ilmu hukum Indonesia yang disampaikannya itu akan lebih bergaung karena menjadi lebih implementatif untuk menuntun pengembangan ilmu hukum nasional Indonesia, yang pada gilirannya juga bakal dimanfaatkan oleh para pengemban hukum praktis dalam melakukan pembentukan hukum, penemuan hukum, pelayanan bantuan hukum, dan aktivitas birokrasi hukum. 


\section{F. Kesimpulan}

Tiga sekuens pemikiran Arief Sidharta mengenai landasan pengembangan hukum teoretis, penalaran hukum, dan ilmu hukum Indonesia merupakan sedikit dari belantara telaahan yang diminatinya. Tiga lapangan kajian tersebut semuanya berada dalam kategori pengembanan hukum teoretis. Tiga area ini telah mempertontonkan pergulatan Arief sebagai seorang teoretisi dan filsuf hukum Indonesia yang tekun dan terus berkarya sampai akhir hayatnya. Perjalanan hidup dan karir akademik yang dijalaninya pada akhirnya membuktikan bahwa Arief adalah sosok langka yang layak dicatat sebagai ikon teoretisi dan filsuf hukum. Lebih tepatnya, ikon pengemban hukum teoretis Indonesia.

Hal itu karena Arief adalah seorang pengemban hukum teoretis yang berjasa memperkenalkan struktur ilmu hukum yang akan digunakannya untuk memberi landasan kefilsafatan dan sifat keilmuan ilmu hukum (nasional) Indonesia. Ranah filsafat yang terlalu abstrak dan ranah ilmu hukum yang terlalu konkret ini dijembatani melalui penelaahan Arief di bidang teori hukum. Di jembatan inilah Arief mempopulerkan penalaran hukum, yaitu suatu cara berpikir problematis tersistematisasi.

Strategi kognisi yang dibangun melalui proyek filsafati dari seseorang bernama Arief Sidharta ini tentu belum benar-benar tuntas, tetapi denah bangunannya (house plan; blueprint) dari bangunan itu sudah dipersiapkan. Sebagaimana layaknya sebuah karya filsafati, denah itu tidak mungkin sekali jadi dan sedetail-detailnya, sehingga diperlukan orang lain yang mampu menyinambungkan pemikirannya ke ranah operasional dari waktu ke waktu. Dari perspektif ini, Bernard Arief Sidharta sudah paripurna menuntaskan misinya sebagai salah satu tokoh ikonik pengemban hukum teoretis Indonesia.

\section{Daftar Pustaka}

Ali, Ahmad. Menguak Teori Hukum (Legal Theory) dan Teori Peradilan (Judicial Jurisprudence) Termasuk Interpretasi Undang-Undang (Legisprudence). Jakarta: Kencana, 2009. 
Anonim. "Pelatihan Penalaran Hukum untuk Komisi Yudisial." https: / / business-law.binus.ac.id/2015/10/22/ pelatihanpenalaran-hukum-untuk-komisi-yudisial/. Diakses 23/10/2020. Apeldoorn, L.J. van. Pengantar Ilmu Hukum. Terjemahan Oetarid Sadino. Jakarta: Pradnya Paramita, 1954.

Aubert, V. Sociology of Law. Middlesex: Penguin Books, 1975.

Austin, J. The Province of Jurisprudence Determined. Cambridge: Cambridge University Press, 1995.

Borght, Gr. van der \& J.D.C. Winkelman. "Penyelesaian Kasus." Jurnal Pro Justitia, 1 (1994): 35-53.

Bruggink, J.J.H. Refleksi tentang Hukum: Pengertian-Pengertian Dasar dalam Teori Hukum. Terjemahan B. Arief Sidharta. Bandung: Citra Aditya Bakti, 2015.

Damardono, Haryo. "Penziarahan Arief Sidharta Demi Ilmu Hukum Indonesia." Dalam Bernard Arief Sidharta: Penziarah Hukum Indonesia, diedit oleh Shidarta, Tristam P. Moeliono, dan Tanius Sebastian, 1-23. Jakarta: HuMa \& Epistema Institute, 2016. Dijk, P. van, dkk. Van Apeldoorn's Inleidingtotde Studievan het Nederlandse

Recht. Achtiende druk. Zwolle: W.E.J. Tjeenk Willink, 1985.

Friedmann, W. Teori dan Filsafat Hukum: Susunan I-III. Terjemahan Muhamad Arifin. Jakarta: Rajawali 1990.

Griffiths, J. "What is Legal Pluralism?” Journal of Legal Pluralism and Unofficial Law, 18, 24 (1986): 1-55.

Henket, M. Teori Argumentasi dan Hukum. Terjemahan B. Arief Sidharta. Bandung: Laboratorium Hukum Fakultas Hukum Universitas Katolik Parahyangan, 2003.

Hutchinson, A.C. dan P.J. Monahan. "Law, Politics, and the Critical Legal Scholars: the Unfolding Drama of American Legal Thought." Standford Law Review, 36, 1 \& 2 (1984): 199-245.

Kartohadiprodjo, Soediman. Pancasila sebagai Pandangan Hidup Bangsa Indonesia. Jakarta: Gatra Pustaka, 2010.

Kusuma-Atmadja, Mochtar dan B. Arief Sidharta, Pengantar Ilmu Hukum: Suatu Pengenalan Pertama Ruang Lingkup Berlakunya Ilmu Hukum, Buku I. Bandung: Alumni, 2009.

Kusuma-Atmadja, Mochtar. "Fungsi dan Perkembangan Hukum 
dalam Pembangunan Nasional.” Dalam Konsep-Konsep Hukum dalam Pembangunan: Kumpulan Karya Tulis Prof. Dr. Mochtar Kusumaatmadja, diedit oleh H.R. Otje Salman dan Eddy Damian, 1-17. Bandung: Alumni, 2002.

Lubis, Todung Mulya dan Alexander Lay. Eds. Kontroversi Hukuman Mati. Jakarta: Penerbit Buku Kompas, 2009.

Nonet, P. dan P. Selznick. Law and Society in Transition: toward Responsive Law. New Brunswick: Transaction Publishers, 2009.

Oktoberina, Sri Rahayu dan Niken Savitri, eds. Butir-Butir Pemikiran dalam Hukum: Memperingati 70 Tahun Prof. Dr. B. Arief Sidharta, S.H. Bandung: Refika Aditama, 2008.

Purbacaraka, Purnadi dan M. Chidir Ali. Disipin Hukum. Bandung: Alumni, 1986.

Purbacaraka, Purnadi dan Soerjono Soekanto. Perihal Kaedah Hukum. Jakarta: Alumni, 1978.

Republik Indonesia, Departemen Pendidikan Nasional. Kamus Besar Bahasa Indonesia. Jakarta: Balai Pustaka, 2005.

Shidarta. "In Search of Scholten's Legacy: the Meaning of the Method of 'Rechtsvinding' for the Current Indonesian Legal Discourse." https: / www.paulscholten.eu/research/article/ in-search-ofscholtens-legacy/. Diakses 20/10/2020.

Shidarta. Hukum Penalaran dan Penalaran Hukum. Buku I: Akar Filosofis. Yogyakarta: Genta Publishing, 2012.

Shidarta. "Membaca Ulang Pemaknaan Keadilan Sosial dalam Gagasan Revolusi Hukum Soediman Kartohadiprodjo.” Jurnal Veritas et Justitia, 1, 1 (2015): 20-38.

Shidarta(Ed.). MochtarKusuma-Atmadjadan TeoriHukum Pembangunan: Eksistensi dan Implikasi. Jakarta: Epistema Institute-HuMa, 2012.

Shidarta. "Posisi Pemikiran Bernard Arief Sidharta dalam Konfigurasi Aliran Pemikiran Hukum (Sebuah Diagnosis Awal).” Dalam Bernard Arief Sidharta Penziarah Hukum Indonesia, diedit oleh Shidarta, Tristam P. Moeliono dan Tanius Sebastian, 25-49. Jakarta: HuMa-Epistema Intitute, 2016.

Sidharta, B. Arief. Ilmu Hukum Indonesia: Upaya Pengembangan Ilmu 
Hukum Sitematik yang Responsif terhadap Perubahan Mayarakat. Bandung: Unpar Press, 2016.

Sidharta, B. Arief. "Penalaran Hukum." Manuskrip, tidak diterbitkan.

Sidharta, B. Arief. "Pengembanan Hukum.” Dalam Bernard Arief Sidharta Penziarah Hukum, diedit oleh Shidarta, Tristam P. Moeliono dan Tanius Sebastian. Jakarta: HuMa-Epistema Intitute, 2016.

Sidharta, Bernard Arief. Refleksi tentang Struktur Ilmu Hukum: Sebuah Penelitian tentang Fundasi Kefilsafatan dan Sifat Keilmuan Ilmu Hukum sebagai Landasan Pengembangan Ilmu Hukum Nasional Indonesia. Bandung: Mandar Maju, cetakan kedua, 2000.

Sidharta, B. Arief. "Revisitasi Pemikiran Prof. Soediman Kartohadiprodjo tentang Pancasila Berkaitan dengan Pengembangan Tatanan Hukum Nasional Indonesia.” Dalam Prof. Mr. Soediman Kartohadiprodjo tentang Pancasila sebagai Pandangan Hidup Bangsa Indonesia, diedit oleh Achmad Suhardi Kartohadiprodjo, dkk., 359-395. Jakarta: Gatra Pustaka, 2010.

Sidharta, B. Arief. "Studi dan Profesi Hukum Hanya untuk Orang Bodoh?” Harian Kompas, 18/10/1979: 4.

Vinke, P. Wat is en Waaroom Rechtssociologie? Kluwer: Deventer, 1970. 